\title{
Is there an association between crown discoloration and pulp necrosis in traumatized permanent teeth? A meta-analysis
}

Bárbara Suelen MOCCELINI(a) Nashalie Andrade de ALENCAR ${ }^{(a)}$ (DD Marcela Baraúna MAGNO(b) Michele BOLAN(a) Lucianne Cople MAIA ${ }^{(b)}$ Mariane CARDOSO(a)

(a) Universidade Federal de Santa Catarina UFSC, School of Dentistry, Department of Pediatric Dentistry, Florianópolis, SC, Brazil.

(b) Universidade Federal do Rio de Janeiro UFRJ, School of Dentistry, Department of Pediatric Dentistry and Orthodontics, Rio de Janeiro, RJ, Brazil.

Declaration of Interests: The authors certify that they have no commercial or associative interest that represents a conflict of interest in connection with the manuscript.

\section{Corresponding Author:}

Mariane Cardoso

E-mail: mariane_cardoso@hotmail.com, mariane.cardoso@ufsc.br

hitps://doi.org/10.1590/1807-3107bor-2020.vol34.0103

Submitted: March 10, 2020

Accepted for publication: June 15, 2020

Last revision: July 13, 2020
Abstract: The present study aimed to identify the scientific evidence regarding the association between crown discoloration and pulp necrosis in traumatized permanent teeth. A systematic literature search was conducted in the PubMed/Medline, Lilacs/BBO, Scopus, Web of Science, Cochrane Library databases, and grey literature. Quality assessment and bias control were carried out according to the Fowkes and Fulton guidelines. Meta-analysis was performed, and the odds ratio was calculated with a $95 \%$ confidence interval. The quality assessment of the evidence was determined for the meta-analysis outcomes using the Grading of Recommendations Assessment, Development and Evaluation (GRADE) approach. From 2,702 studies identified, five articles met the inclusion criteria. One among these showed no methodological soundness and was excluded from the meta-analysis, and the remaining four studies were included in the meta-analysis. The total number of traumatized permanent teeth evaluated in the metaanalysis was 367 . The results showed a positive association between crown discoloration and pulp necrosis in permanent teeth. Teeth with crown discoloration showed 23 times more chance to present pulp necrosis than teeth without crown discoloration (OR 23.82 [1.25, 452.87]; $p=0.03)$, with a very low certainty of evidence. There is a significant association between crown discoloration and pulp necrosis of traumatized permanent teeth. Due to the very low strength of evidence according to GRADE, this result should be viewed with caution.

Keywords: Dental Pulp Necrosis; Dentition, Permanent; Tooth Injuries; Tooth Discoloration.

\section{Introduction}

A common complication of dental trauma is pulp necrosis. ${ }^{1,2,3}$ Its prevalence rate in traumatized permanent teeth varies from 26.9 to $73.3 \%, 1,2,4,5,6$ depending mainly on the type of dental trauma and the stage of root development. Among immature permanent teeth, pulp necrosis ranges from 13.0 to $66.7 \%$ and in mature permanent teeth, between 42.0 to $87.0 \% .{ }^{2,4,6}$ Signs of trauma that indicate diagnosis of pulp necrosis may manifest in the subsequent weeks, months, or years after the injury., 
Regular controls for monitoring the state of the pulp after dental trauma are necessary for an early detection of complications. ${ }^{2}$ As a result, a follow-up protocol is very important for a correct diagnosis. ${ }^{8}$

The following criteria are proposed by studies for the classification of non-vital pulp after dental trauma: abscess/fistula, periapical bone rarefaction, inflammatory root resorption, arrested root development, persistent crown discoloration, and loss of pulpal sensibility (sensitive tests). ${ }^{9,10}$ Traumatized teeth that show persistent crown discoloration or loss of pulpal sensibility are only considered necrotic when associated with one of the following signs: a) abscess/fistula, or b) obvious periapical bone rarefaction, or c) inflammatory external root resorption. ${ }^{1,6,9,10,11}$

Loss of sensibility and color change can be temporary, ${ }^{7,12}$ indicating pulp damage, but they do not determine a definitive pulp necrosis diagnosis ${ }^{10}$ since revascularization and regeneration/repair of the traumatized pulp can occur..$^{13}$

Dental trauma is more frequent in maxillary central incisors, ${ }^{2,5,6,8}$ and post-traumatic complications can result in esthetic compromise. ${ }^{14}$ Due to its compromising oral esthetics, crown discoloration is a clinical alteration that afflicts the patient ${ }^{15}$ and raises doubts in the clinician. Even in cases where there is no evidence of pulp necrosis, color change suggests alteration of the pulpal tissue ${ }^{10}$ with uncertainties regarding the prognosis, ${ }_{16}^{16}$ which might progress to necrosis. When facing this clinical alteration, the clinician needs to establish a follow-up schedule. This involves the interval between consultations and the actual time of tooth monitoring, which is not well defined in the literature or in the guideline of The International Association of Dental Traumatology $(\mathrm{IADT})^{17}$ for permanent teeth. Knowledge concerning the association or not of crown discoloration with pulp necrosis can help optimize a specific follow-up protocol for teeth with crown discoloration, aiming for immediate endodontic treatment in cases of necrosis or upkeep of follow-ups in cases of maintenance of pulp vitality. Thus, the aim of the present systematic review was to verify if there is an association between crown discoloration and pulp necrosis in traumatized permanent teeth.

\section{Methodology}

\section{Focused question}

The present systematic review was designed in order to answer the following focused question: Is there an association between crown discoloration and pulp necrosis in traumatized permanent teeth?

\section{Protocol and registry}

The present systematic review with meta-analysis was reported according to the PRISMA protoco ${ }^{18}$ and the Maia and Antonio guideline. ${ }^{19}$ The developed protocol was registered in the PROSPERO database under the number CRD42017068650.

\section{Literature search strategy}

An electronic search was performed in the databases PubMed/Medline, Lilacs/BBO, Scopus, Web of Science, Cochrane Library, and also in the grey literature catalogs ProQuest, OpenGrey, Capes Thesis Bank, and Google Scholar (Table 1) on March 2018 and updated on August 2019. MeSH terms, synonyms, related terms, and free terms were used and combined with the Boolean operators 'AND' and 'OR', respecting each databases' rules. No language or date of publication restrictions were applied. When necessary, articles were read in full to determine the selection. A manual search was also performed in the reference lists of all included studies to identify possible studies that were not retrieved through the electronic search.

\section{Eligibility criteria}

The Population, Exposure, Comparisons, and Outcome (PECO) ${ }^{20}$ strategy was used to identify observational studies in traumatized permanent teeth $(\mathrm{P})$ with $(\mathrm{E})$ or without $(\mathrm{C})$ pulp necrosis and the association with crown discoloration $(\mathrm{O})$. The following types of articles were excluded from the present review: literature reviews, conference abstracts, letters, in vitro studies, case reports; studies with follow-up of less than one month; studies with malignancies included in the sample; studies where the crown discoloration was identified after endodontic treatment; sample overlap; studies that did not present 
Table 1. Search strategy used in the systematic review.

\# 1 "dentition, permanent"[MeSH Terms]) OR "permanent dentition"[Title/Abstract]) OR "permanent teeth"[Title/Abstract]) OR "permanent tooth"[Title/Abstract]) OR "tooth injuries"[MeSH Terms]) OR "tooth injuries" [Title/Abstract]) OR "dental lesions" [Title/Abstract]) OR "dental injuries"[Title/ Abstract]) $O R$ "dental trauma"[Title/Abstract]) OR "traumatic injury"[Title/Abstract]) OR injuries[Title/ Abstract]) OR injury[Title/Abstract]) OR trauma[Title/Abstract]) OR traumatized[Title/Abstract]) OR traumatic[Title/Abstract

\#2 "dental pulp necrosis"[MeSH Terms]) OR "dental pulp necrosis"[Title/Abstract]) OR necrotic[Title/

PubMed

Lilacs

Scopus

Web of Science
Abstract]) OR pulp[Title/Abstract]) OR pulps[Title/Abstract]) OR pulpal[Title/Abstract]) OR necrosis[Title/ Abstract]) OR necroses[Title/Abstract]

\#3 “dental pulp"[MeSH Terms]) OR “dental pulp"[Title/Abstract]) OR dental[Title/Abstract]) OR pulp[Title/ Abstract]) OR vitality[Title/Abstract]

\#4 crowns[MeSH Terms]) OR "crowns, dental"[Title/Abstract]) OR coronal[Title/Abstract]) OR discolouration[Title/Abstract]) OR discoloration[Title/Abstract]) OR discolored[Title/Abstract]) OR colour[Title/Abstract]) OR color[MeSH Terms]) OR color[Title/Abstract])

\section{\#1 AND \#2 AND \#3 AND \#4}

\# $1 \mathrm{MH}$ : "permanent dentition" OR MH: "permanent teeth" OR MH: "permanent tooth" OR MH: "dentição permanente" OR MH: "Tooth Injuries" OR MH: "dental lesions" OR "dental injuries" OR "dental trauma" OR "traumatic injury" OR injuries OR "traumatismos de los dientes" OR "injúria traumática" OR "lesion traumática"

\#2 MH: "dental pulp necrosis" OR MH: necrotic OR MH: pulp OR MH: pulps OR MH: pulpal OR necrosis OR necroses

\#3 "dental pulp" OR dental OR pulp OR vitality OR MH: "pulp vitality" OR "vital pulp" OR MH: "vitalidade pulpar" OR MH: "vitalidad pulpar"

\#4 crown OR crowns OR coronal OR discolouration" OR discolour OR discolor OR color OR colour OR descoloração\#1 AND \#2 AND \#3 AND \#4

\# 1 ( ( TITLE-ABS-KEY ( "dentition permanent")) OR ( TITLE-ABS-KEY ( " tooth injuries ") ) OR ( TITLEABS-KEY ("dental lesions")) OR ( TITLE-ABS-KEY ("dental injuries") ) OR ( TITLE-ABS-KEY ("dental trauma" ) ) OR ( TITLE-ABS-KEY ("traumatic injury" ) ) OR ( TITLE-ABS-KEY ( injuries) ) OR ( TITLE-ABSKEY ( injury )) OR ( TITLE-ABS-KEY (" trauma ")) OR ( TITLE-ABS-KEY (" traumatized ") ) OR ( TITLEABS-KEY (" traumatic"))

\#2 ( TITLE-ABS-KEY ( "dental pulp necrosis" )) OR ( TITLE-ABS-KEY ("pulp necrosis")) OR ( TITLEABS-KEY (necrotic)) OR (TITLE-ABS-KEY (pulp )) OR (TITLE-ABS-KEY ("pulps")) OR (TITLE-ABSKEY ("pulpal ")) OR (TITLE-ABS-KEY (necrosis)) OR (TITLE-ABS-KEY (necroses))

\#3 (( TITLE-ABS-KEY ("dental pulp")) OR ( TITLE-ABS-KEY ( "pulp vitality")) OR (TITLE-ABS-KEY ( pulp )) OR ( TITLE-ABS-KEY (vitality ))

\#4 (( TITLE-ABS-KEY (crowns )) OR( TITLE-ABS-KEY ( crown )) OR (TITLE-ABS-KEY (coronal)) OR TITLE-ABS-KEY (discoloration )) OR ( TITLE-ABS-KEY (discoloured)) OR ( TITLE-ABS-KEY (colour) ) OR ( TITLE-ABS-KEY ( color ))

\section{\# 1 AND \#2 AND \#3 AND \#4}

\#1 TS=("permanent dentition" OR "tooth injuries" OR "dental lesions" OR "dental injuries" OR "dental trauma" OR "traumatic injury" OR injuries OR injury OR trauma OR trauma OR traumatized OR traumatic

\#2 TS=("dental pulp necrosis" OR necrotic OR pulp OR pulps OR pulpal OR necrosis OR necroses)

\#3 TS=("dental pulp" OR dental OR pulp OR vitality)

\#4 TS=( crown OR crowns OR coronal OR discolouration

OR discoloured OR discolored OR colour OR color)

\#1 AND \#2 AND \#3 AND \#4

Continue... 


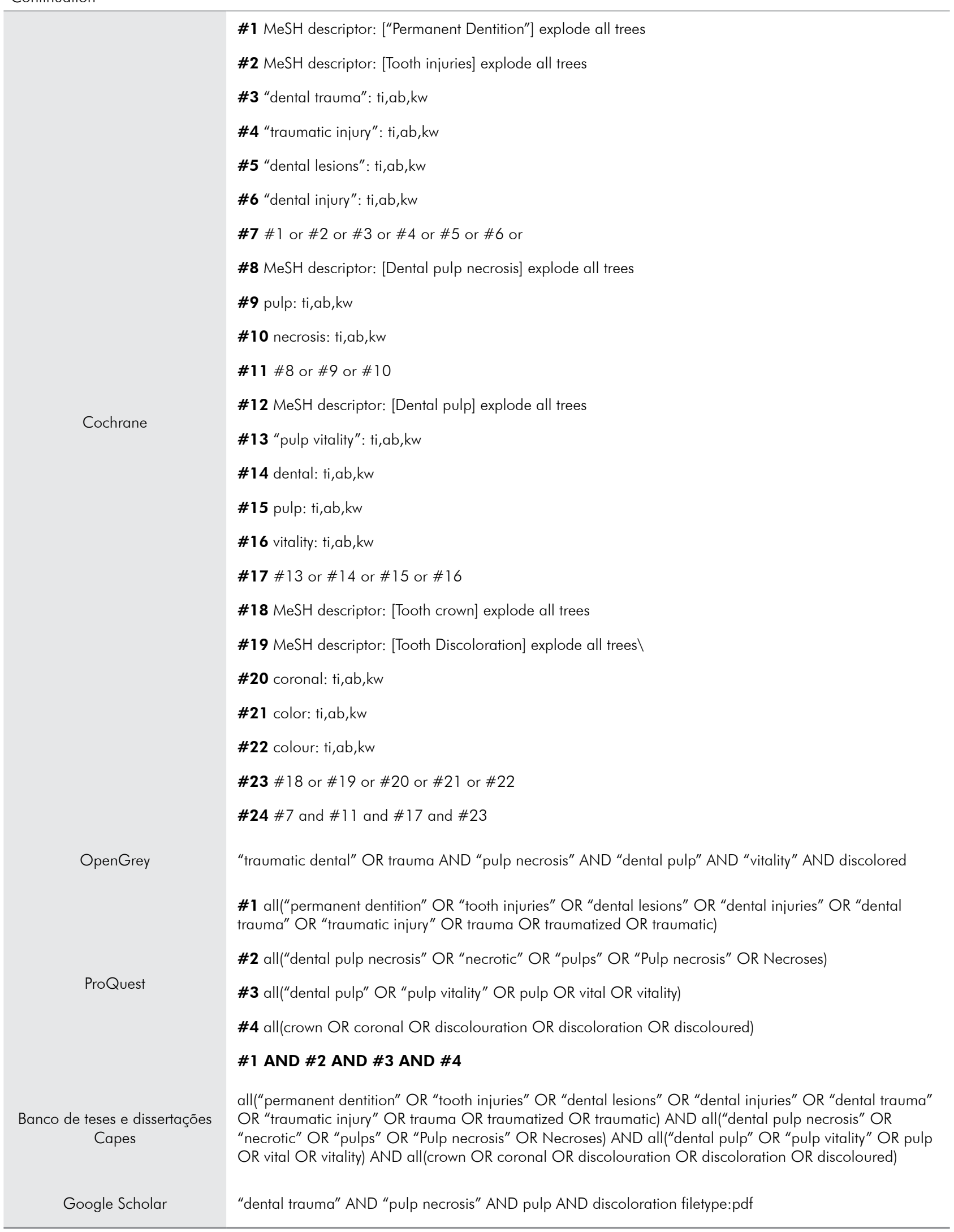


traumatized teeth without crown discoloration; studies in which clinical and/or radiographic signs of pulp necrosis have not been reported; studies on avulsed teeth and their replantation, and studies with pulp necrosis diagnosed only by the presence of crown discoloration.

The eligibility criteria were used by two independent reviewers (BSM and NAA) to select the studies based on titles and abstracts from the databases, grey literature, and manual searches. When the title and abstract did not provide enough information, the full text was analyzed with the objective of determining its eligibility. Studies that appeared in more than one database were considered only once. After applying the eligibility criteria, the results of both reviewers were compared, and the study was only discarded in case of both reviewers' consensus. Any disagreement was resolved through discussion with a third review author (MC).

The Mendeley Desktop ${ }^{\odot}$ software (version 1.17.1, 2008-2017 Mendeley Ltd., Elsevier Inc., USA) was used for management and selection of the references.

\section{Data extraction}

Two reviewers (BSM and NAA) read the full articles and extracted the information independently. The following data were extracted from each eligible study: authors, year of publication, study country, study design, number of participants included in the study, age of the participants in years, study methods (evaluation criteria), results (number of traumatized permanent teeth, number of teeth with pulp necrosis, number of teeth without pulp necrosis, number of teeth with and without crown discoloration). Disagreements between the reviewers were solved by discussion with a third review author (MC). In studies with missing data, the authors were contacted by e-mail for further data details or for additional information.

\section{Quality assessment and risk of bias}

The methodological quality and bias control of eligible studies was carried out independently by the two reviewers (BSM and NAA) in accordance with the guidelines and critical appraisal described by Fowkes and Fulton. ${ }^{21}$ Any differences between the two examiners were resolved with a third reviewer (MC).

This quality assessment enables the classification of cross-sectional, cohort, controlled trial, and casecontrol studies. The checklist contains questions on study design, study sample representativeness, control group characteristics, quality of measurements and outcomes, completeness, and distorting influences. When verifying the criteria for each guideline, the importance of failures concerning their expected effects on the results was scored as "major" $(++)$ or "minor" (+) problem, and "no problem" (0). For items where the checklist question was not applicable, 'NA' was registered. For this evaluation, the authors elaborated a standardization for each item of the checklist (Table 2).

The corresponding authors were contacted in order to clarify doubts. Disagreements between the reviewers regarding the quality assessment and risk of bias were resolved by consensus with a third review author.

\section{Summary measures and meta-analysis}

In the quantitative analysis, only studies with "NO" as a response in the Summary Questions were included. The criteria used for traumatized teeth where the association between the presence or absence of pulp necrosis and the presence or absence of permanent crown discolorations. For the diagnosis of pulp necrosis, clinical (abscess and/or fistula) and/or radiographic signs were considered (periapical bone rarefaction or inflammatory external root resorption). For conventional pulp tests (electric pulp test and cold pulp test), the negative response was considered only with the presence of a radiographic sign.

The extracted data were analyzed using the RevMan software (Review Manager v. 5.3, The Cochrane Collaboration; Copenhagen, Denmark) to assess the relationship between pulp necrosis and crown discoloration in permanent teeth. The prevalence of crown discoloration (events) and the total number of teeth with (case) and without (control) pulp necrosis were used to calculate the odds ratio with a $95 \%$ confidence interval (CI). 
Table 2. Domains and Risk of Bias considered in accordance with the items of the guidelines and critical appraisal described by Fowkes and Fulton. ${ }^{21}$

\begin{tabular}{|c|c|c|}
\hline Guideline & Checklist & Description \\
\hline $\begin{array}{l}\text { Study design appropriate } \\
\text { to objective? }\end{array}$ & Objective & If they agreed $(0)$ was assigned. \\
\hline \multirow{16}{*}{$\begin{array}{l}\text { Study sample } \\
\text { representative? }\end{array}$} & \multirow{3}{*}{$\begin{array}{l}\text { Source of } \\
\text { sample }\end{array}$} & [0] when well described \\
\hline & & {$[+]$ partial information } \\
\hline & & {$[++]$ when not informed } \\
\hline & \multirow{3}{*}{$\begin{array}{l}\text { Sampling } \\
\text { method }\end{array}$} & [0] probabilistic \\
\hline & & {$[+]$ not probabilistic } \\
\hline & & {$[++]$ not reported } \\
\hline & \multirow{4}{*}{ Sample size } & $\begin{array}{l}\text { For studies without the sample calculation, } 145 \text { teeth were considered as an ideal sample size } \\
\text { according to Moccelini et al. }{ }^{22}\end{array}$ \\
\hline & & [0] did sample calculation \\
\hline & & {$[+]$ with sample $>145$} \\
\hline & & {$[++]$ with sample $<145$} \\
\hline & \multirow{3}{*}{$\begin{array}{l}\text { Entry criteria/ } \\
\text { exclusions }\end{array}$} & [0] inclusion and exclusion criteria \\
\hline & & {$[+]$ only one of the criteria } \\
\hline & & {$[++]$ criteria not reported } \\
\hline & \multirow{3}{*}{$\begin{array}{l}\text { Non- } \\
\text { respondents }\end{array}$} & [0] completed clinical records/sheets \\
\hline & & {$[+]$ incomplete/partially clinical records } \\
\hline & & $\begin{array}{c}{[++] \text { does not report the data of the patient's clinical records/how many patients did not }} \\
\text { participate in the follow-up }\end{array}$ \\
\hline \multirow{9}{*}{$\begin{array}{l}\text { Control group } \\
\text { acceptable? }\end{array}$} & \multirow{3}{*}{$\begin{array}{l}\text { Definition of } \\
\text { controls }\end{array}$} & {$[0]$ the comparison group was adequate } \\
\hline & & {$[+]$ the comparison group showed small failures (e.g. just clinical evaluation) } \\
\hline & & $\begin{array}{l}{[++] \text { the comparison group was not adequate, which could cause distortions (when the evaluation }} \\
\text { used to collect information regarding pulp necrosis was different for the comparison group) }\end{array}$ \\
\hline & \multirow{3}{*}{$\begin{array}{l}\text { Source of } \\
\text { controls }\end{array}$} & {$[0]$ all participants from the same source and the source is representative } \\
\hline & & {$[+]$ the characteristics for both groups showed small distortions (e.g. root development) } \\
\hline & & $\begin{array}{l}{[++] \text { the source of the comparison was not adequate for the purpose of the study (different source }} \\
\text { of sample and/or the distribution of the sample characteristics was distinct between the groups) }\end{array}$ \\
\hline & \multirow{3}{*}{$\begin{array}{l}\text { Comparable } \\
\text { characteristics }\end{array}$} & {$[0]$ equivalent degree of eruption of the sample } \\
\hline & & {$[+]$ small range of degree of eruption } \\
\hline & & {$[++]$ not reported or the degree of eruption was not adequate for the purpose of the study } \\
\hline \multirow{9}{*}{$\begin{array}{l}\text { Quality of measurements } \\
\text { and outcomes? }\end{array}$} & \multirow{3}{*}{ Validity } & {$[0]$ with complete data about criteria for evaluation and diagnosis } \\
\hline & & {$[+]$ only partial data } \\
\hline & & {$[++]$ the studies did not provide the adequate criteria for evaluation of sequelae } \\
\hline & \multirow{3}{*}{ Reproducibility } & [0] reported kappa value and in the case of only one examiner performing the intra-rate evaluation \\
\hline & & {$[+]$ for a study with more than one examiner, if only the inter-rater evaluation was performed } \\
\hline & & $\begin{array}{l}{[++] \text { for studies in which the reliability of the Cohen's kappa and intra-class correlations (ICCs) }} \\
\text { measurements was not performed, inter-rater (if more than one examiner) and/or intra-rate (if only } \\
\text { one or more than one examiner) }\end{array}$ \\
\hline & \multirow{3}{*}{ Quality control } & $\begin{array}{l}\text { [0] for studies that presented measures for data quality control in which they described the } \\
\text { statistical methods, and that standardized procedures and training were adopted to ensure the } \\
\text { quality of information obtained through patient records }\end{array}$ \\
\hline & & {$[+]$ study performed without only one/or two the factors } \\
\hline & & $\begin{array}{l}{[++] \text { for studies that did not present measures for data quality control (monitoring), and who }} \\
\text { did not describe statistical methods in which standardization and training procedures were not } \\
\text { adopted and reported to ensure the quality of information obtained through patient records, since } \\
\text { they may have deficiencies in completeness }\end{array}$ \\
\hline
\end{tabular}

Continue... 


\begin{tabular}{|c|c|c|}
\hline \multirow{11}{*}{ Completeness? } & \multirow{3}{*}{ Compliance } & $\begin{array}{l}\text { [0] for studies that performed standardization of the electric pulp testing and radiographic } \\
\text { examination }\end{array}$ \\
\hline & & $\begin{array}{c}{[+] \text { for studies that did not perform standardization of the electric pulp testing (if performed) or }} \\
\text { radiographic examination }\end{array}$ \\
\hline & & $\begin{array}{c}{[++] \text { for studies that did not perform standardization of the radiographic examination and electric }} \\
\text { pulp testing (if both were performed) }\end{array}$ \\
\hline & \multirow{3}{*}{ Missing data } & [0] all required data provided (frequency, number, $p$ value) \\
\hline & & {$[+]$ incomplete data not affecting completion } \\
\hline & & {$[++]$ incomplete results, and exclusion of important data that compromise completion } \\
\hline & \multirow{3}{*}{$\begin{array}{l}\text { Confounding } \\
\text { factors }\end{array}$} & $\begin{array}{c}\text { [0] (dental caries) if used as an exclusion factor and in the confounding of statistical analysis or } \\
\text { article discussion }\end{array}$ \\
\hline & & {$[+]$ when used only in the discussion } \\
\hline & & {$[++]$ if the research did not mention the considered factor (dental caries) } \\
\hline & \multirow[b]{2}{*}{$\begin{array}{l}\text { Distortion } \\
\text { reduced by } \\
\text { analysis }\end{array}$} & {$[0]$ used multiple regression and when the confounding factor was excluded } \\
\hline & & $\begin{array}{c}{[+] \text { did not perform multiple regression, however, when the confounding factor was excluded }} \\
{[++] \text { did not perform multiple regression to reduce influences and did not use confounding }} \\
\text { factors }\end{array}$ \\
\hline Summary & $\begin{array}{l}\text { Bias - Are } \\
\text { the results } \\
\text { erroneously } \\
\text { biased in } \\
\text { a certain } \\
\text { direction? }\end{array}$ & \multirow{3}{*}{$\begin{array}{l}\text { "YES" or "NO" answers were assigned to each question. If the answers to the three questions were } \\
\text { "NO", the article could be judged as solid (low risk of bias). }\end{array}$} \\
\hline \multirow[t]{2}{*}{ Questions } & $\begin{array}{l}\text { Confounding } \\
\text { - Are there } \\
\text { any serious } \\
\text { confounding } \\
\text { or other } \\
\text { distorting } \\
\text { influences? }\end{array}$ & \\
\hline & $\begin{array}{l}\text { Chance - Is } \\
\text { it likely that } \\
\text { the results } \\
\text { occurred by } \\
\text { chance? }\end{array}$ & \\
\hline
\end{tabular}

Random effect models were employed because the studies were not functionally equivalent and the objective was to generalize the results from the meta-analysis (type of exam used for the diagnose of pulp necrosis and mean age were different between studies). ${ }^{23}$ Heterogeneity was tested using the $\mathrm{I}^{2}$ index and, if necessary, sensitivity analyses were conducted to estimate and verify the influence of studies, one by one, on the subgroup and pooled results when heterogeneity was substantial or considerable (50-100\%, p < 0.05). ${ }^{24}$ Only studies free of bias were included in the meta-analysis. If some of the information needed for the meta-analysis was absent from any of the selected studies, the authors were contacted to provide the missing data.

\section{Quality of evidence}

The assessment of quality of evidence was determined for the meta-analysis outcomes using the Grading of Recommendations Assessment, Development and Evaluation (GRADE) approach. ${ }^{25}$ Observational studies start as low evidence, and the quality of the body of evidence decreases to very low if serious or very serious issues related to risk of bias, inconsistency, indirectness, imprecision, and publication bias are detected. On the other hand, the quality of evidence could increase if the influence of all plausible confounding factors would reduce a demonstrated effect, or suggest a spurious effect, and if the magnitude of effect is large or very large. As a result, the quality of the evidence can vary from very low to high. 


\section{Results}

A flow diagram (Figure 1) describes the study selection process. The search identified a total of 2,702 titles/abstracts stemming from databases. After removal of duplicates, 1,207 studies remained and were analyzed (reading of titles and abstracts) according to the study criteria. Five studies ${ }^{5,12,26,27,28}$ were included for qualitative synthesis, while four ${ }^{5,12,27,28}$ were used for the final meta-analysis.

\section{Data extraction}

The main characteristics of included studies are presented in Table 3. The descriptive observational study design was adopted for all studies,,$^{5,12,26,27,28}$ and all studies were conducted in university settings. 5,12,26,27,28 Two studies were conducted in Brazil, ${ }^{5,28}$ one in Sweden, ${ }^{12}$ one in the US, ${ }^{26}$ and one in Nigeria. ${ }^{27}$ Two studies evaluated teeth with intrusive luxation ${ }^{5,28}$ and one with root fracture, ${ }^{12}$ the other studies did not report the type of dental trauma evaluated. The study of Oginni et al. ${ }^{27}$ did not inform the number and age of patients. Only one study by Holcomb and Gregory ${ }^{26}$ did not provide/confirm information or answer the contact by e-mail.

\section{Quality assessment and risk of bias}

The quality assessment and bias control of the 5 selected studies are presented in Table 4 according to the guideline described by Fowkes and

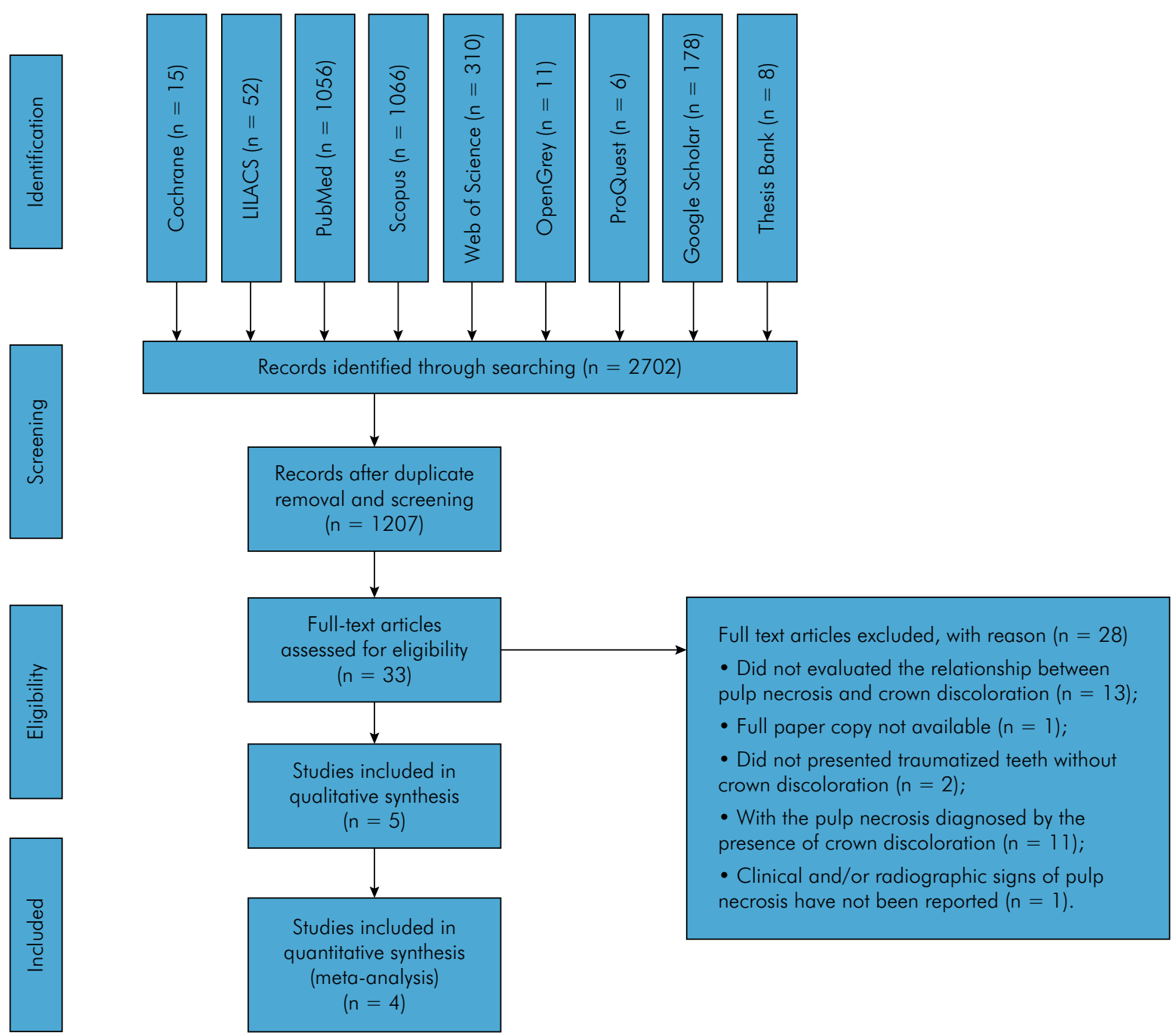

Figure 1. Flowchart diagram of literature search and selection criteria according to the PRISMA statement. 
Table 3. Data extracted from the included studies.

\begin{tabular}{|c|c|c|c|c|c|c|c|c|c|}
\hline $\begin{array}{l}\text { Author, year, } \\
\text { country }\end{array}$ & $\begin{array}{l}\text { Sample } \\
\text { size }\end{array}$ & Source of study & $\begin{array}{l}\text { Age } \\
\text { range } \\
\text { (years) }\end{array}$ & $\begin{array}{l}\text { Type of } \\
\text { dental } \\
\text { trauma }\end{array}$ & Follow-up & $\begin{array}{c}\mathrm{N} \text { of } \\
\text { traumatized } \\
\text { teeth* }\end{array}$ & $\begin{array}{l}\text { Exam for } \\
\text { pulp necrosis } \\
\text { diagnosis }\end{array}$ & $\begin{array}{l}\text { Description of } \\
\text { teeth }\end{array}$ & $\begin{array}{l}\text { Statistical analysis } \\
\text { and study result }\end{array}$ \\
\hline $\begin{array}{l}\text { Holcomb } \\
\text { and Gregory, } \\
1967^{26} \text {, USA }\end{array}$ & 34 & $\begin{array}{l}\text { United States } \\
\text { Naval Academy }\end{array}$ & $7-16$ & $\mathrm{NI}$ & $\begin{array}{l}\text { The teeth } \\
\text { were } \\
\text { evaluated } \\
\text { over a four- } \\
\text { year interval }\end{array}$ & 40 & $\begin{array}{c}\text { Electric } \\
\text { pulp testing, } \\
\text { clinical and/or } \\
\text { radiographic }\end{array}$ & $\begin{array}{l}\text { Of the forty teeth, } \\
\text { only three showed } \\
\text { pulp necrosis; } \\
\text { of these, two } \\
\text { presented crown } \\
\text { discoloration. }\end{array}$ & Descriptive analysis. \\
\hline $\begin{array}{l}\text { Malmgren } \\
\text { and Hübel, } \\
2012^{12} \text {, } \\
\text { Sweden }\end{array}$ & 39 & $\begin{array}{l}\text { Department } \\
\text { of Paediatric } \\
\text { Dentistry at the } \\
\text { Eastman } \\
\text { Institute in } \\
\text { Stockholm }\end{array}$ & 7-19 & $\begin{array}{l}\text { Root } \\
\text { fracture }\end{array}$ & $\begin{array}{c}\text { period } \\
\text { ranged from } \\
1 \text { to } 9 \text { years }\end{array}$ & 42 & $\begin{array}{c}\text { Electric } \\
\text { pulp testing, } \\
\text { clinical and/or } \\
\text { radiographic }\end{array}$ & $\begin{array}{l}\text { Only one tooth } \\
\text { maintained crown } \\
\text { discoloration } \\
\text { and showed pulp } \\
\text { necrosis during } \\
\text { follow-up. }\end{array}$ & $\begin{array}{l}\text { No significant } \\
\text { difference was found } \\
\text { in prognosis between } \\
\text { teeth with and without } \\
\text { discoloration } \\
(p=0.76) \text {. }\end{array}$ \\
\hline $\begin{array}{l}\text { Neto et al., } \\
2009^{5} \text {, } \\
\text { Brazil }\end{array}$ & 12 & $\begin{array}{c}\text { Center of } \\
\text { Buccodental } \\
\text { Trauma } \\
\text { (CENTRAU) of } \\
\text { the University of } \\
\text { Ceará }\end{array}$ & $\begin{array}{c}7-14 \\
\text { years } \\
\text { and } 8 \\
\text { months }\end{array}$ & $\begin{array}{l}\text { Intrusive } \\
\text { luxation }\end{array}$ & $\begin{array}{l}\text { Follow-ups } \\
\text { at } 2 \text { weeks, } \\
1,3 \text {, and } 6 \\
\text { months and } \\
\text { annually. }\end{array}$ & 15 & $\begin{array}{l}\text { Thermal } \\
\text { pulp testing, } \\
\text { clinical and/or } \\
\text { radiographic }\end{array}$ & $\begin{array}{l}\text { Eleven teeth } \\
\text { showed pulp } \\
\text { necrosis, } \\
\text { one tooth } \\
\text { presented crown } \\
\text { discoloration. }\end{array}$ & $\begin{array}{l}\text { Descriptive analysis } \\
\text { and relative risk. }\end{array}$ \\
\hline $\begin{array}{l}\text { Oginni et al., } \\
2009^{27}, \\
\text { Nigeria }\end{array}$ & $\mathrm{NI}$ & $\begin{array}{l}\text { Oral Diagnosis } \\
\text { Unit and the } \\
\text { Conservative } \\
\text { Clinic of the }\end{array}$ & $\mathrm{NI}$ & $\mathrm{NI}$ & $\begin{array}{l}\text { The teeth } \\
\text { were } \\
\text { evaluated } \\
\text { sometime }\end{array}$ & 276 & $\begin{array}{c}\text { Electric } \\
\text { pulp testing, } \\
\text { clinical and/or } \\
\text { radiographic }\end{array}$ & $\begin{array}{l}\text { All teeth } \\
\text { evaluated } \\
\text { presented pulp } \\
\text { canal obliteration. } \\
\text { Seventy-five teeth } \\
\text { showed pulp } \\
\text { necrosis and all } \\
\text { of these teeth } \\
\text { presented crown } \\
\text { discoloration. }\end{array}$ & $\begin{array}{l}\text { No differences were } \\
\text { found between teeth } \\
\text { with a negative } \\
\text { response to the } \\
\text { sensitivity test and } \\
\text { periapical bone } \\
\text { rarefaction (pulp } \\
\text { necrosis) and yellow, } \\
\text { grey or normal color. }\end{array}$ \\
\hline $\begin{array}{l}\text { Soares et al., } \\
2018^{28} \\
\text { Brazil }\end{array}$ & 25 & $\begin{array}{c}\text { Dental } \\
\text { Trauma } \\
\text { Surveillance } \\
\text { Center (DTSC) } \\
\text { of the Federal } \\
\text { University of Rio } \\
\text { de Janeiro, }\end{array}$ & $6-12$ & $\begin{array}{l}\text { Intrusive } \\
\text { luxation }\end{array}$ & $\begin{array}{l}\text { Followed for } \\
\text { a minimum } \\
\text { period of } \\
\text { three months } \\
\text { after initial } \\
\text { attendance }\end{array}$ & 34 & $\begin{array}{c}\text { Electric } \\
\text { pulp testing, } \\
\text { clinical and/or } \\
\text { radiographic }\end{array}$ & $\begin{array}{l}\text { Twelve teeth } \\
\text { presented pulp } \\
\text { necrosis and } \\
\text { none of the } \\
\text { evaluated teeth } \\
\text { showed crown } \\
\text { discoloration. }\end{array}$ & $\begin{array}{l}\text { Descriptive analysis, } \\
\text { chi-squared test } \\
(p<0.05) \text { and logistic } \\
\text { regression analysis ( } \\
\quad<0.05)\end{array}$ \\
\hline
\end{tabular}

*Total calculated by the author; NI: not informed.

Fulton. ${ }^{21}$ Regarding sample, Moreira Neto et al. ${ }^{5}$ and Oginni et al., ${ }^{27}$ in the item source of sample, described partial information and it was considered a minor problem. All studies used convenience sampling and it was also considered a minor problem. Regarding the item sample size, Holcomb and Gregory, ${ }^{26}$ Malmgren 
Table 4. Quality assessment Fowkes and Fulton. ${ }^{21}$

\begin{tabular}{|c|c|c|c|c|c|c|}
\hline Guideline & Checklist & $\begin{array}{c}\text { Holcomb } \\
\text { and Gregory, } \\
1967^{26}\end{array}$ & $\begin{array}{l}\text { Malmgren and } \\
\text { Hübel, } 2012^{12}\end{array}$ & $\begin{array}{l}\text { Moreira } \\
\text { Neto et al., } \\
2009^{5}\end{array}$ & $\begin{array}{l}\text { Oginni et al., } \\
2009^{27}\end{array}$ & $\begin{array}{c}\text { Soares et al., } \\
2018^{28}\end{array}$ \\
\hline \multirow{5}{*}{$\begin{array}{l}\text { Study design } \\
\text { appropriate to } \\
\text { the objective? }\end{array}$} & \multicolumn{6}{|c|}{ Objective } \\
\hline & Prevalence & 0 & 0 & 0 & 0 & 0 \\
\hline & Prognosis & NA & NA & NA & NA & NA \\
\hline & Treatment & NA & NA & NA & NA & NA \\
\hline & Cause & NA & NA & NA & NA & NA \\
\hline \multirow{5}{*}{$\begin{array}{l}\text { Study sample } \\
\text { representative? }\end{array}$} & Source of sample & 0 & 0 & + & + & 0 \\
\hline & Sampling method & + & + & + & + & + \\
\hline & Sample size & ++ & ++ & ++ & + & ++ \\
\hline & Entry criteria/exclusions & + & 0 & 0 & 0 & 0 \\
\hline & Non-respondents & + & 0 & 0 & 0 & 0 \\
\hline \multirow{4}{*}{$\begin{array}{l}\text { Control group } \\
\text { acceptable? }\end{array}$} & Definition of controls & 0 & 0 & 0 & 0 & 0 \\
\hline & Source of controls & 0 & 0 & 0 & 0 & 0 \\
\hline & Matching/randomization & NA & NA & NA & NA & NA \\
\hline & Comparable characteristics & 0 & 0 & 0 & 0 & 0 \\
\hline \multirow{4}{*}{$\begin{array}{l}\text { Quality of } \\
\text { measurements } \\
\text { and outcomes? }\end{array}$} & Validity & 0 & 0 & 0 & 0 & 0 \\
\hline & Reproducibility & ++ & ++ & 0 & 0 & 0 \\
\hline & Blindness & $\mathrm{NA}$ & NA & NA & NA & NA \\
\hline & Quality control & + & 0 & 0 & 0 & 0 \\
\hline \multirow{4}{*}{ Completeness? } & Compliance & + & 0 & 0 & 0 & 0 \\
\hline & Dropouts & NA & NA & NA & NA & NA \\
\hline & Deaths & NA & NA & NA & NA & NA \\
\hline & Missing data & 0 & + & 0 & 0 & 0 \\
\hline \multirow{5}{*}{$\begin{array}{l}\text { Distorting } \\
\text { influences? }\end{array}$} & Extraneous treatments & NA & NA & NA & NA & NA \\
\hline & Contamination & NA & NA & NA & NA & NA \\
\hline & Changes over time & NA & NA & NA & NA & NA \\
\hline & Confounding factors & ++ & 0 & 0 & 0 & 0 \\
\hline & Distortion reduced by analysis & ++ & + & 0 & 0 & 0 \\
\hline \multirow{3}{*}{$\begin{array}{l}\text { Summary } \\
\text { questions }\end{array}$} & $\begin{array}{l}\text { Bias - Are the results erroneously } \\
\text { biased in a certain direction? }\end{array}$ & YES & NO & $\mathrm{NO}$ & NO & NO \\
\hline & $\begin{array}{c}\text { Confounding - Are there any serious } \\
\text { confounding or other distorting } \\
\text { influences? }\end{array}$ & YES & NO & NO & NO & NO \\
\hline & $\begin{array}{c}\text { Chance - Is it likely that the results } \\
\text { occurred by chance? }\end{array}$ & YES & NO & NO & NO & NO \\
\hline
\end{tabular}

0: no problem; +: minor problem; ++: major problem; NA: not applicable

and Hübel, ${ }^{12}$ Moreira Neto et al. ${ }^{5}$ and Soares et al. ${ }^{28}$ did not perform sample size calculation and the sample was $<145$ teeth, and it was considered a major problem, and Oginni et al. ${ }^{27}$ did not perform the sample size calculation and the sample was $>145$ teeth, and it was considered a minor problem.
The article of Holcomb and Gregory ${ }^{26}$ did not mention the exclusion criteria, and it was considered a minor problem. In the item non-respondents, Holcomb and Gregory ${ }^{26}$ described partial information in the clinical records, and it was considered a minor problem. 
In quality of measurements and outcomes, in the item reproducibility, Holcomb and Gregory ${ }^{26}$ and Malmgren and Hübel ${ }^{12}$ did not perform Cohen's kappa reliability test and intra-class correlations (ICCs), and it was considered a major problem. For the item quality of control, Holcomb and Gregory ${ }^{26}$ did not describe any statistical methods and presented deficiencies in completeness of the information obtained through patient records, and it was considered a minor problem.

In completeness, in the item compliance, Holcomb and Gregory ${ }^{26} \mathrm{did}$ not perform standardization of the radiographic examination, and it was considered a minor problem. For the item missing data, Malmgren and Hübel ${ }^{12}$ in the discussion showed incomplete data without affecting completion, and it was considered a minor problem.

In relation to distorting influences, in the item confounding factors, Holcomb and Gregory ${ }^{26}$ did not mention dental caries, which was considered a factor, and the item was considered a major problem. For the item distortion reduced by analysis, Holcomb and Gregory ${ }^{26}$ did not perform a multiple regression and did not include confounding factors, and it was considered a major problem. Malmgren and Hübe ${ }^{12}$ did not perform a multiple regression, but the authors excluded teeth with dental caries, and it was considered a minor problem.

Lastly, the questions regarding "Bias", "Chance" and "Confounding" for the four studies ${ }^{5,12,27,28}$ were answered with a NO. For the study of Holcomb and Gregory ${ }^{26}$ the three questions were answered with a YES. Therefore, the articles by Malmgren and Hübel, ${ }_{1}^{12}$ Moreira Neto et al., ${ }^{5}$ Oginni et al., ${ }^{27}$ and Soares et al. ${ }^{28}$ wereclassified with high methodological quality and Holcomb and Gregory ${ }^{26}$ had no methodological soundness (Table 4).

\section{Meta-analysis and quality of evidence}

The meta-analysis was conducted only with the data available in the studies included in the present systematic review. The Holcomb and Gregory ${ }^{26}$ study was classified as having serious confounding or other distorting influences, and was excluded from the meta-analysis. Four studies were included in the quantitative synthesis. ${ }^{5,12,27,28}$

The heterogeneity of the four studies was substantial but not significant $\left(I^{2}=56 \% p=0.11\right)$. In an attempt to reduce heterogeneity, sensitivity analysis was performed by removing the studies one by one. ${ }^{24}$ During this stage, the heterogeneity ranged from $0 \%$ to $74 \%$. However, the removal of these studies from the analysis nullified the heterogeneity without altering the overall significance of the result. Thus, the final meta-analysis included the four studies.

The pooled meta-analysis showed a positive association between crown discoloration and pulp necrosis in permanent teeth. Teeth with crown discoloration presented 23 times higher chance to present pulp necrosis than teeth without crown discoloration (OR 23.84 [1.23, 464.06]; $\mathrm{p}=0.04$ ) (Figure 2), with a very low quality of evidence (Table 5).

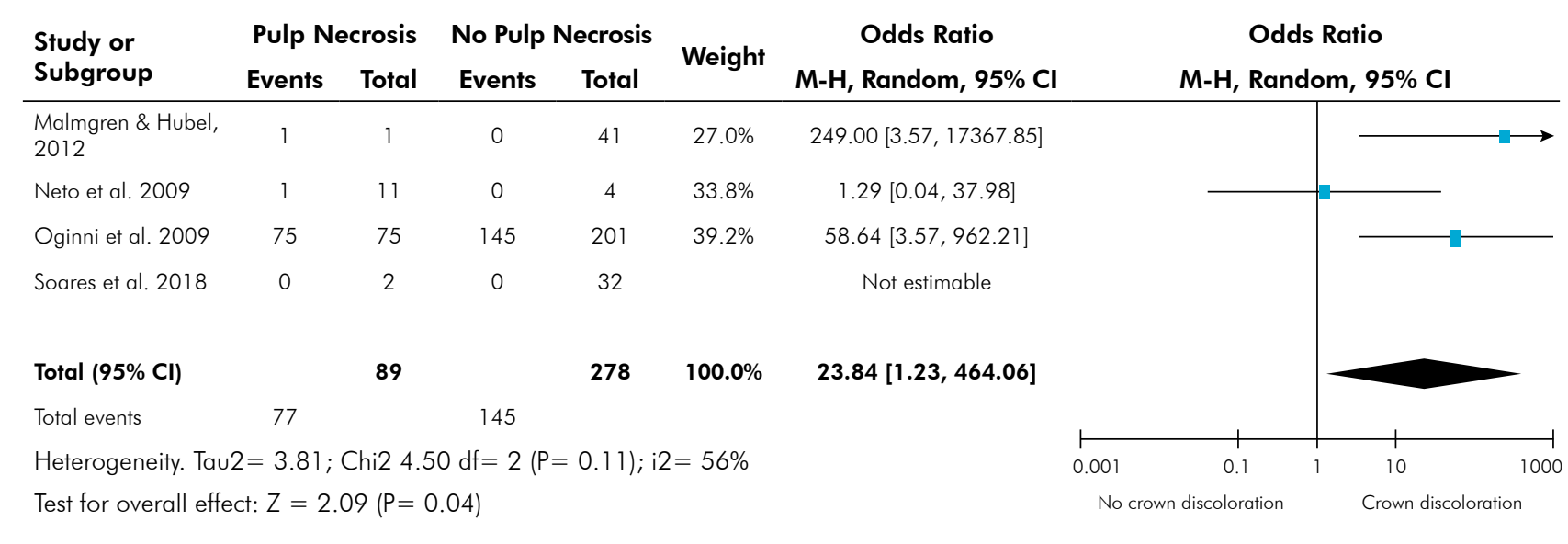

Figure 2. Forest plot the association between pulp necrosis and crown discoloration in traumatized permanent teeth. 
Is there an association between crown discoloration and pulp necrosis in traumatized permanent teeth? A meta-analysis

Table 5. Evidence profile. Association of crown discoloration and pulp necrosis in traumatized permanent teeth.

\begin{tabular}{|c|c|c|c|c|c|c|c|c|c|c|c|}
\hline \multirow[b]{2}{*}{$\begin{array}{l}\mathrm{n} \\
\text { studies }\end{array}$} & \multirow[b]{2}{*}{ Study design } & \multicolumn{5}{|c|}{ Certainty assessment } & \multicolumn{2}{|c|}{$\mathrm{n}$ of patients } & \multicolumn{2}{|c|}{ Effect } & \multirow[b]{2}{*}{ Certainty } \\
\hline & & $\begin{array}{c}\text { Risk of } \\
\text { bias }\end{array}$ & Inconsistency & Indirectness & Imprecision & $\begin{array}{c}\text { Other } \\
\text { considerations }\end{array}$ & $\begin{array}{c}\text { Crown } \\
\text { discoloration }\end{array}$ & $\begin{array}{l}\text { No crown } \\
\text { discoloration }\end{array}$ & $\begin{array}{c}\text { Relative } \\
(95 \% \mathrm{Cl}) \\
\text { OR } \\
23.82\end{array}$ & $\begin{array}{l}\text { Absolute } \\
(95 \% \mathrm{CI})\end{array}$ & \\
\hline & & & & & & & 77 cases 1 & 45 controls & & - & $\oplus \bigcirc \bigcirc 0$ \\
\hline 3 & $\begin{array}{l}\text { observational } \\
\text { studies }\end{array}$ & $\begin{array}{c}\text { not } \\
\text { serious }\end{array}$ & serious $b, c$ & not serious & $\begin{array}{c}\text { very } \\
\text { serious }{ }^{a, d}\end{array}$ & $\begin{array}{l}\text { very strong } \\
\text { association }\end{array}$ & - & $0.0 \%$ & $\begin{array}{l}(1.25 \text { to } \\
452.87)\end{array}$ & $\begin{array}{c}0 \text { fewer } \\
\text { per } \\
1.000 \\
\text { (from } 0 \\
\text { fewer to } \\
0 \text { fewer) }\end{array}$ & Very low \\
\hline
\end{tabular}

$\mathrm{Cl}$ : Confidence interval; OR: Odds ratio; a. Total number of events is less than that requested by GRADE for the evaluation of studies with an odds ratio. b. Some variation in the effect estimates across studies with overlap of confidence intervals associated with the effect estimates. c. Heterogeneity higher than $50 \%$ but not significant. d. Lower and higher confidence intervals greater than $25 \%$ of OR.

\section{Discussion}

Crown discoloration is a common sequela after trauma, ${ }^{29}$ easily identified by the patient due to esthetic impairment, ${ }^{15}$ and therefore, it is common for the patient to seek dental care to treat this alteration. ${ }^{30}$ This sequela indicates loss of pulp vitality when associated with at least one more sign of necrosis (periapical bone rarefaction, external inflammatory reabsorption). ${ }^{9,10}$ However, in many cases, crown discoloration is the only sign of alteration after dental trauma, leaving the dentist uncertain because, despite suggesting pulp necrosis, it is still not an indication for endodontic treatment. ${ }^{9}$ In order to elucidate this question, the present systematic review and metaanalysis showed that there is an association between crown discoloration of the traumatized permanent tooth and pulp necrosis.

Although the definitive diagnosis of pulp necrosis is only confirmed by clinical observation of the pulp after endodontic access of the tooth or by histological analysis, ${ }^{31}$ the literature agrees that for the beginning of endodontic treatment, the absence of pulp vitality can be identified through periapical radiolucency signs, abscess/fistula, ${ }^{32}$ and external inflammatory root resorption ${ }^{33}$ regardless of the history of trauma. Thus, for traumatized teeth, the discoloration of the crown alone is insufficient to confirm pulp necrosis according to Andreasen ${ }^{9}$ and Malmgren and Rübel, ${ }^{12}$ since in the first year after dental trauma, the prognosis of the pulp is uncertain. ${ }^{6}$
Although the literature presents a significant number of studies evaluating crown discoloration and pulp necrosis of traumatized permanent teeth, most do not meet the eligibility criteria of the present study for not distinguishing among necrotic teeth with and without discoloration, or not reporting association data. Among the five studies included, the study by Oginni et al. ${ }^{27}$ reported the absence of association between crown discoloration and pulp necrosis and the other studies presented descriptive data.

Another important aspect worth highlighting is the time of crown discoloration after trauma, that is, whether it was transient or permanent. For the present review, only permanent crown discolorations were considered (at the end of follow-up) and there was no distinction of color shades. Discoloration is defined as transient when it is identified soon after the trauma, remaining altered during the period of pulp healing. ${ }^{34}$ Transient discoloration is described as a favorable prognostic sign in the study by Malmgren and Rübel, ${ }^{12}$ where 8 of the 9 traumatized teeth with color change and negative response to the sensitivity tests at the beginning of follow-up returned to their normal color within the period from 4 to 6 months and responded positively to the sensitivity tests. The permanent color change is defined at the end of the follow-up (there is no period stipulated in the literature), attributed to a possible pulp infection with necrotic tissue autolysis and extravasation of the products into the dentine., ${ }^{9,34}$ 
Other aspects such as the age of the patient at the time of trauma, the type of dental trauma, the stage of root development, ${ }^{8,10,31}$ and the combination of types of dental trauma ${ }^{10,35}$ are factors that influence the sequelae and prognosis of the traumatized tooth. Dental trauma is more frequent in children and adolescents, ${ }^{2}$ and immature permanent teeth have a better prognosis, with a better healing process compared to mature permanent teeth ${ }^{2,35}$ after dental trauma such as pulp exposure, root fracture, and luxation injury. $2,17,35$

Several factors that may influence the prognosis of the traumatized permanent tooth can be found in the analyzed studies in this systematic review and may have influenced the relationship between pulp necrosis and crown discoloration. In addition, the high heterogeneity, confirmed in the meta-analysis, could have influenced the results. Malmgren and Hübel ${ }^{12}$ evaluated 7 to 19 -year-old patients with intraalveolar root fracture. Of the 42 teeth evaluated, only one had crown discoloration and pulp necrosis. Full root formation with closed apex occurred in $80.9 \%$, with half-closed apex in $14.3 \%$, and full root formation with an open apex in two teeth $(4.8 \%) .{ }^{12}$ Root fracture is a rare trauma in permanent teeth and has shown good prognosis. ${ }^{2,36}$ Moreira Neto et al. ${ }^{5}$ assessed the treatment approach of teeth with severe intrusion. Of the fifteen traumatized permanent teeth, $73.3 \%$ had an incomplete root formation and $26.6 \%$ had a complete root formation at the time of trauma. Of the immature teeth, four teeth were vital with pulp canal obliteration and without color change. All mature teeth presented pulp necrosis and no crown discoloration. The early stage of root development (immature) had a positive effect in that sample..$^{5}$ Intrusive luxation is a very severe injury and the healing process may be accompanied by a high number of post-trauma complications, principally pulp necrosis. ${ }^{2,5}$ In the study by Moreira Neto et al., ${ }^{5}$ eleven teeth presented pulp necrosis and one, crown discoloration. Moreover, of the all teeth evaluated, $66.6 \%$ showed an additional injury, which increases the risk of pulp necrosis. ${ }^{5}$ Oginni et al. ${ }^{27}$ did not discriminate the types of dental trauma, however, all teeth presented pulp canal obliteration and $27.2 \%$ were necrotic. The study by
Soares et al. ${ }^{28}$ evaluated only luxation injury and no tooth showed discoloration.

Crown discoloration was not considered in any of the four studies as a criterion for the diagnosis of pulp necrosis. The studies performed the diagnosis of pulp necrosis in different ways, and the teeth that presented a negative response to the electric or thermal pulp test were associated with another clinical/radiographic sign of pulp necrosis (abscess/ fistula and/or periapical bone rarefaction and/or external inflammatory resorption). 5,12,26,27,28 Only in the studies by Moreira Neto et al. ${ }^{5}$ and Oginni et al., ${ }^{27}$ the measurements reliability for the radiographic diagnosis were measured, which may justify the heterogeneity of the included studies.

Although radiographic examination is of great importance after dental trauma and can indicate, in many cases, endodontic treatment, Andreasen and Kahler ${ }^{13}$ report that traumatic teeth during the pulp healing process can present radiographic changes that can generate diagnostic confusion. In some cases, a periapical radiolucency or pronounced expansion of the periodontal ligament may be identified. ${ }^{34}$ Transient apical breakdown (TAB), a temporary process with evident resorption of the ape $x^{37}$ or periapical region may lead to an overdiagnosis ${ }^{9}$ and should be differentiated from periapical replacement resorption ${ }^{37}$ and periapical bone rarefaction. ${ }^{35} \mathrm{In}$ addition, in the study by Andreasen, ${ }^{34}$ TAB was concomitantly identified with color and sensibility changes after luxation injuries, which returned to their normal conditions during the follow-up period.

The assessment of the methodological quality of the studies included in the systematic review is very important because it is related to the critical and detailed evaluation of the studies. ${ }^{38}$ All primary studies included in that systematic review showed observational analytical design that allowed the guide described by Fowkes and Fulton ${ }^{21}$ to properly assess the methodological quality and risk of bias. Only the study by Holcomb and Gregory ${ }^{26}$ did not show methodological soundness, because it had problems in one of the three summary questions (confounding factors), since there was no confirmation of the exclusion of teeth with caries. 
The studies by Malmgren and Hübel, ${ }^{12}$ Moreira Neto et al., ${ }^{5}$ Oginni et al..$^{27}$ and Soares et al. ${ }^{28}$ were considered to have good methodological quality, and were included in the quantitative analysis; however, the heterogeneity was considered substantial. The heterogeneity observed between studies may be related to the variability between the characteristics of the previously mentioned samples and diagnostic tests. ${ }^{24}$

Although the meta-analysis included four studies, Soares et al. ${ }^{28}$ results were not computed in the effect size (OR 23.84) because no event (tooth discoloration) was described in this study results. The only rate effect that computes results with no events is the risk difference (RD). However, RD could not be applied in the present meta-analysis since it requires the incidence in the exposed and unexposed groups, which was not available in the included studies as they all had cross-sectional designs and no prospective analysis. Although no events were reported, the authors opted to maintain Soares et al. ${ }^{28}$ in the quantitative analysis to provide results that were representative of the studies.

Although the results of the present systematic review and meta-analysis showed a positive association between crown discoloration and pulp necrosis, some aspects need to be analyzed with caution before the indication of endodontic treatment: a) crown discoloration is not a pathognomonic sign of necrosis, ${ }^{9} \mathrm{~b}$ ) part of the studies did not differentiate between open and closed teeth, c) transient and permanent discolorations are not clearly identified, and d) the level of evidence in the studies is very low.

Among the options of a) initiating endodontic treatment having only crown discoloration as a sign of pulpal alteration and b) follow up teeth with discoloration until another clinical and/or radiographic sign of pulp necrosis is identified, the latter seems to be more prudent and reduce the risk of unnecessary endodontics. Andreasen and Kahler ${ }^{39}$ emphasize that clinicians should consider signs and symptoms in addition to radiographic evaluations before intervention with pulp therapy.

In this sense, although the follow-up advocated by the IADT for traumatized permanent teeth is dependent on the type of trauma, ${ }^{17}$ based on the present systematic review, after identifying a crown discoloration on a permanent tooth with trauma, irrespective of the shade, the clinician should recommend a specific clinical and radiographic follow-up, that is, with shorter intervals between visits. Thus, in cases where the tooth with crown discoloration is actually necrotic, the final diagnosis through other clinical/radiographic signs could be performed early and endodontic treatment initiated immediately, favoring the prognosis of the treatment. On the other hand, in cases where no clinical/radiographic signs that confirm pulp necrosis are identified, the tooth would remain in follow-up, without endodontic intervention. It is important that further studies determine a specific follow-up protocol for traumatized teeth with crown discoloration.

One limitation of the present systematic review and meta-analysis was that the studies included did not have the same objective as the present study and did not report confirmation of the diagnosis of pulp necrosis after endodontic access (gold standard). Therefore, because the GRADE method indicated a very low quality of the evidence, more prospective and retrospective studies are needed specifically designed to evaluate the present association and, thus, support the current evidence. Further research is also needed to determine a specific protocol for monitoring traumatized permanent teeth with crown discoloration.

In conclusion, there seems to be an association between the clinical sign of crown discoloration and pulp necrosis in traumatized permanent teeth. However, these data need to be carefully evaluated in view of the low quality of the evidence. In addition, specific monitoring of the teeth with crown discoloration is fundamental to minimize damages and favor the prognosis.

\section{Acknowledgments}

The present study was financed in part by the Coordenação de Aperfeiçoamento de Pessoal de Nível Superior - Brasil (CAPES) - Finance Code 001. We would like to thank José J. S. Moreira Neto, Adeleke O. Oginni and Barbro Malmgren. 


\section{References}

1. Lee R, Barrett EJ, Kenny DJ. Clinical outcomes for permanent incisor luxations in a pediatric population. II. Extrusions. Dent Traumatol. 2003 Oct;19(5):274-9. https://doi.org/10.1034/j.1600-9657.2003.00208.x

2. Hecova H, Tzigkounakis V, Merglova V, Netolicky J. A retrospective study of 889 injured permanent teeth. Dent Traumatol. 2010 Dec;26(6):466-75. https://doi.org/10.1111/i.1600-9657.2010.00924.x

3. Robertson A, Robertson S, Norén JG. A retrospective evaluation of traumatized permanent teeth. Int J Paediatr Dent. 1997 Dec;7(4):217-26. https://doi.org/10.1046/j.1365-263X.1997.00046.x

4. Nikoui M, Kenny DJ, Barrett EJ. Clinical outcomes for permanent incisor luxations in a pediatric population. III. Lateral luxations. Dent Traumatol. 2003 Oct;19(5):280-5. https://doi.org/10.1034/i.1600-9657.2003.00209.x

5. Moreira Neto JJ, Gondim JO, Carvalho FM, Giro EM. Longitudinal clinical and radiographic evaluation of severely intruded permanent incisors in a pediatric population. Dent Traumatol. 2009 Oct;25(5):510-4. https://doi.org/10.1111/j.1600-9657.2009.00789.x

6. Humphreys K, Al Badri S, Kinirons M, Welbury RR, Cole BO, Bryan RA, et al. Factors affecting outcomes of traumatically extruded permanent teeth in children. Pediatr Dent. 2003 Sep-Oct;25(5):475-8.

7. Andreasen FM, Andreasen JO. Diagnosis of luxation injuries: the importance of standardized clinical, radiographic and photographic techniques in clinical investigations. Endod Dent Traumatol. 1985 Oct;1(5):160-9. https://doi.org/10.1111/j.1600-9657.1985.tb00651.x

8. Soares TR, Luiz RR, Risso PA, Maia LC. Healing complications of traumatized permanent teeth in pediatric patients: a longitudinal study. Int J Paediatr Dent. 2014 Sep;24(5):380-6. https://doi.org/10.1111/ipd.12082

9. Andreasen FM. Pulpal healing after luxation injuries and root fracture in the permanent dentition. Endod Dent Traumatol. 1989 Jun;5(3):111-31. https://doi.org/10.1111/i.1600-9657.1989.tb00348.x

10. Jacobsen I. Criteria for diagnosis of pulp necrosis in traumatized permanent incisors. Scand J Dent Res. 1980 Aug;88(4):306-12. https://doi.org/10.1111/j.1600-0722.1980.tb01231.x

11. Viduskalne I, Care R. Analysis of the crown fractures and factors affecting pulp survival due to dental trauma. Stomatologija. 2010;12(4):109-15.

12. Malmgren B, Hübel S. Transient discoloration of the coronal fragment in intra-alveolar root fractures. Dent Traumatol. 2012 Jun;28(3):200-4. https://doi.org/10.1111/j.1600-9657.2011.01073.x

13. Andreasen FM, Kahler B. Pulpal response after acute dental injury in the permanent dentition: clinical implications-a review. J Endod. 2015 Mar;41(3):299-308. https://doi.org/10.1016/i.joen.2014.11.015

14. Kaur P, Singh S, Mathur A, Makkar DK, Aggarwal VP, Batra M, et al. Impact of Dental Disorders and its Influence on Self Esteem Levels among Adolescents. J Clin Diagn Res. 2017 Apr;1 1(4):ZC05-08. https://doi.org/10.7860/JCDR/2017/23362.9515

15. Bersezio C, Martín J, Mayer C, Rivera O, Estay J, Vernal R, et al. Quality of life and stability of tooth color change at three months after dental bleaching. Qual Life Res. 2018 Dec;27(12):3199-207. https://doi.org/10.1007/s11136-018-1972-7

16. Arwill T, Henschen B, Sundwall-Hagland I. The pulpal reaction in traumatized permanent incisors in children aged 9-18. Odontol Tidskr. 1967 Apr;75(2):130-47.

17. Diangelis AJ, Andreasen JO, Ebeleseder KA, Kenny DJ, Trope M, Sigurdsson A, et al.; International Association of Dental Traumatology. International Association of Dental Traumatology guidelines for the management of traumatic dental injuries: 1. Fractures and luxations of permanent teeth. Dent Traumatol. 2012 Feb;28(1):2-12. https://doi.org/10.1111/j.1600-9657.2011.01103.x

18. Moher D, Shamseer L, Clarke M, Ghersi D, Liberati A, Petticrew M, et al.; PRISMA-P Group. Preferred reporting items for systematic review and meta-analysis protocols (PRISMA-P) 2015 statement. Syst Rev. 2015 Jan;4(1):1. https://doi.org/10.1186/2046-4053-4-1

19. Maia LC, Antonio AG. Systematic reviews in dental research. A guideline. J Clin Pediatr Dent. 2012;37(2):117-24. https://doi.org/10.17796/icpd.37.2.h606137vj3826v61

20. Needleman IG. A guide to systematic reviews. J Clin Periodontol. 2002;29(s3 Suppl 3):6-9;37-8. https://doi.org/10.1034/j.1600-051X.29.s3.15.x

21. Fowkes FG, Fulton PM. Critical appraisal of published research: introductory guidelines. BMJ. 1991 May;302(6785):1136-40. https://doi.org/10.1136/bmi.302.6785.1136

22. Moccelini BS, Alencar NA, Bolan M, Magno MB, Maia LC, Cardoso M. Pulp necrosis and crown discoloration: a systematic review and meta-analysis. Int J Paediatr Dent. 2018 Jun;28(5):432-42. https://doi.org/10.1111/ipd.12372

23. Borenstein M, Hedges LV, Higgins JP, Rothstein HR. Introduction to Meta-Analysis. West Sussex: John Wiley \& Sons, Ltd.; 2009.

24. Higgins JP, Green S. Cochrane handbook for systematic reviews of interventions. Oxford: The Cochrane Collaboration; 2011. (Cochrane book series).

25. Ryan R, Hills S. How to grade the quality of the evidence: Cochrane Consumers and Communication Group. 2016 [cited 2019 Dec 18]. Available from: http://cccrgcochraneorg/author-resources 
Is there an association between crown discoloration and pulp necrosis in traumatized permanent teeth? A meta-analysis

26. Holcomb JB, Gregory WB Jr. Calcific metamorphosis of the pulp: its incidence and treatment. Oral Surg Oral Med Oral Pathol. 1967 Dec;24(6):825-30. https://doi.org/10.1016/0030-4220(67)90521-X

27. Oginni AO, Adekoya-Sofowora CA, Kolawole KA. Evaluation of radiographs, clinical signs and symptoms associated with pulp canal obliteration: an aid to treatment decision. Dent Traumatol. 2009 Dec;25(6):620-5. https://doi.org/10.1111/j.1600-9657.2009.00819.x

28. Soares TR, Silva LP, Salazar SL, Luiz RR, Risso PA, Maia LC. Profile of intrusive luxation and healing complications in deciduous and permanent teeth - a retrospective study. Acta Odontol Scand. 2018 Nov;76(8):567-71. https://doi.org/10.1080/00016357.2018.1481226

29. Camp JH. Diagnosis dilemmas in vital pulp therapy: treatment for the toothache is changing, especially in young, immature teeth. J Endod. 2008 Jul;34(7 Suppl):S6-12. https://doi.org/10.1016/i.joen.2008.03.020

30. Thomas MS, Denny C. Medication-related tooth discoloration: a review. Dent Update. 2014 Jun;41(5):440-2, 445-7. https://doi.org/10.12968/denu.2014.41.5.440

31. Levin LG, Law AS, Holland GR, Abbott PV, Roda RS. Identify and define all diagnostic terms for pulpal health and disease states. J Endod. 2009 Dec;35(12):1645-57. https://doi.org/10.1016/i.joen.2009.09.032

32. Abbott PV, Yu C. A clinical classification of the status of the pulp and the root canal system. Aust Dent J. 2007 Mar;52(1 Suppl):S17-31. https://doi.org/10.1111/j.1834-7819.2007.tb00522.x

33. Ne RF, Witherspoon DE, Gutmann JL. Tooth resorption. Quintessence Int. 1999 Jan;30(1):9-25.

34. Andreasen FM. Transient apical breakdown and its relation to color and sensibility changes after luxation injuries to teeth. Endod Dent Traumatol. 1986 Feb;2(1):9-19. https://doi.org/10.1111/j.1600-9657.1986.tb00118.x

35. Lauridsen E, Hermann NV, Gerds TA, Ahrensburg SS, Kreiborg S, Andreasen JO. Combination injuries 3. The risk of pulp necrosis in permanent teeth with extrusion or lateral luxation and concomitant crown fractures without pulp exposure. Dent Traumatol. 2012 Oct;28(5):379-85. https://doi.org/10.1111/j.1600-9657.2011.01100.x

36. Andreasen JO, Andreasen FM, Mejàre I, Cvek M. Healing of 400 intra-alveolar root fractures. 1. Effect of pre-injury and injury factors such as sex, age, stage of root development, fracture type, location of fracture and severity of dislocation. Dent Traumatol. 2004 Aug;20(4):192-202. https://doi.org/10.1111/j.1600-9657.2004.00279.x

37. González OL, Vera J, Orozco MS, Mancera JT, González KV, Malagón GV. Transient apical breakdown and its relationship with orthodontic forces: a case report. J Endod. 2014 Aug;40(8):1265-7. https://doi.org/10.1016/i.joen.2014.01.006

38. Zeng X, Zhang Y, Kwong JS, Zhang C, Li S, Sun F, et al. The methodological quality assessment tools for pre-clinical and clinical studies, systematic review and meta-analysis, and clinical practice guideline: a systematic review. Journal of Evidence-Based Medicine. 2015 Feb;8(1):2-10. https://doi.org/10.1111/jebm.12141

39. Andreasen FM, Kahler B. Diagnosis of acute dental trauma: the importance of standardized documentation: a review. Dent Traumatol. 2015 Oct;31(5):340-9. https://doi.org/10.1111/edt.12187 